J. Gen. Appl. Microbiol.

Vol. 6, No. 3, 1960

\title{
A TAXONOMIC STUDY ON THE GENUS RHODOTORULA
}

\author{
(Continued) \\ TAKEZI HASEGAWA, ISAO BANNO and SAKAE YAMAUCHI \\ Institute For Fermentation, Osaka \\ Received for publication, June 3, 1960
}

II. THE SUBGENUS FLAVOTORULA NOV. SUBGEN.

\section{The relationship between Cryptococcus and Rhodotorula}

The genus Cryptococcus was originally created by Kützing (1933) (1) for a mucous micro-organism whose cells were spherical and capsulated. But, because the author did not fully described the fact that his organism was an asporogenous yeast, another name Torula given by Turpin (1838) (2) has been more commonly used for it.

Vuillemin (3) revived the name Cryptococcus in 1901 for the asporogenous nonfermenting yeasts from animal tissues. Guilliermond (1912) (4) recognized Cryptococcus sensu Vuillemin as the name for the pathogenic yeasts, but in his Clef Dichotomique (1928) (5) reduced it to synonym with Torula. Ciferri and Redaeldi (1928) (6) pointed out that the confusion in the systematic classification of the asporogenous budding fungi was increased by Vuillemin's acceptance of the generic name, and they adopted the single name Torulopsis BerLese ( 7 ) for the pathogenic and non-pathogenic asporogenous yeasts in place of Torula and Cryptococcus.

Notwithstanding the facts above mentioned, the name Cryptococcus has been generally used in the medical circles, for instance, Dopge (1935) (8), Benham (1935) (9), Henrici (1941) (10) etc.

In 1952, LodDER and KREger-van RIJ (11) gathered pathogenic and nonpathogenic capsulated yeasts in the genus Cryptococcus and separated the genus from Torulopsis on the inability of fermentation of sugars and on the capsule formation of cells. In this method, they have really succeeded in the differentiation between the above genera. But instead of it, a troublesome problem of the distinction between Cryptococcus and Rhodotorula has been brought on a taxonomic discussion.

Cryptococcus was defined by those authors as a non-fermenting asporogenous yeast which formed extracellular polysaccharide positive in the iodine reaction and which has capsulated cells and did not produce carotenoid pigments. The differences between the genus and Rhodotorula were also considered to be on the same points. Later, NAKAYAMA et al. (1954) (12) and 
Peterson et al. (1954) (13) proved the presence of carotenoid pigments in several strains of Cryptococcus, and furthermore, among the Rhodotorulas, three strains; i.e. Rht. peneaus (PhafF et al. 1952) (14), Rht. macerans (SonNe Frederiksen, 1956) (15) and Rht. glutinis var. infirmominiata (Lodder et al. 1958) (16) were reported to give the positive iodine reaction with their extracellular polysaccharide.

As to the above facts, Lodder and KREger-van RIJ (1955) (17) concluded that the relationship between Rhodotorula and Cryptococcus was closer than that to be expected from their classification into separate subfamilies. However, the capsule formation in them still remains to be discussed for the clarification of this relationship.

Mager and Aschner (1947) (18) observed a dissociation phenomenon in a Cryptococcus (Torulopsis rotundata). They obtained two types of the colony from a parent culture. One was the large, flat, rapidly growing, grayish, mucoid colonies ( $\mathrm{M}$ form), and another small, convex, slow growing, drylooking colonies ( $\mathrm{S}$ form). $\mathrm{M}$ form cells had broad capsule similar to the parent cells, but most of the $\mathrm{S}$ form cells were devoid of the capsule.

LODDER and KREGER-van RIJ (11) found a strain of Cryptococcus albidus in their culture collection, which presented a culture appearance which was not mucous, but dry and dull. Little capsule formation was observed in this strain, but the production of a starch-like substance could be readily demonstrated. They stated that since originally it was mucous, the above phenomenon was similar to the variation detected by MAGER and Aschner.

In addition to the above observations, capsulated cells were found in several strains of Rhodotorula (HASEgawa et al. 1960) (19). These strains were Rht. glutinis strain miniata, Rht. glutinis strain koishikawensis, Rht. glutinis var. dairenensis, Rht. glutinis var. aurantiaca, Rht. rubra strain corallina, Rht. rubra strain simplex and Rht. peneaus (Plate II). From these facts, the differentiation between Cryptococcus and Rhodotorula established by LODDER and KREGER-van RIJ (11) resulted in loss of its varidity.

For the re-examination of the asporogenous yeast on the carotenogenesis, 29 yellow or pale colored strains except Rhodotorula were selected from 72 species of the genera defined by LodDER and KREGER-vaN RIJ (1952); i.e. Cryptococcus (5 spp.), Torulopsis (22 spp.), Pityrosporum (1 sp.), Brettanomyces (3 spp.), Candida (30 spp.), Kloekera (5 spp.), Trigonopsis (1 sp.) and Trichosporon (4 spp.). The selected cultures were incubated on a rotary shaker at $28^{\circ} \mathrm{C}$ for 4 days or more, and the extraction of the pigments from them was performed with acetone and petroleum ether.

Among the above genera, Cryptococcus was only found to produce carotenoid pigments. However in the genus, five strains belonging to $\mathrm{Cr}$. neoformans did not afford the pigment, notwithstanding many efforts of treatment of cells necessary for the extraction of the pigments, i.e. the grinding with a quartz crystal, the sonic oscillation $(20 \mathrm{KC})$, the freezing and thawing, the autolysis, etc. (Table 3). Moreover it was also found that the pigmenta- 
tion in the above strains of $\mathrm{Cr}$. neoformans was not influenced to any extent by diphenylamine even in the doses to inhibit the pigment production in the

Table 3. Nature of crude pigment extracts from Cryptococcus cells.

\begin{tabular}{|c|c|c|c|}
\hline Strains & Color of cells & $\begin{array}{l}\text { Petroleum } \\
\text { ether extract }\end{array}$ & $\begin{array}{l}\text { Light absorption } \\
\text { maxima }\end{array}$ \\
\hline T. gelatinosa (3 cul.) & pale yellow & yellow & $450(420,480) \mathrm{m} \mu$ \\
\hline T. albida (2 cul.) & yellowish white & slightly yellow & 450 \\
\hline Tp. liquefaciens & $\begin{array}{l}\text { pale yellowish } \\
\text { brown }\end{array}$ & slightly yellow & 450 \\
\hline Cr. albidus CBS str. & pale yellow & yellow & $450(420,480)$ \\
\hline T. laurentii & dull yellow & yellow & $450(420,480)$ \\
\hline T. aurea (2 cul.) & pale yellow & yellow & $450(420,480)$ \\
\hline T. flavescens (2 cul.) & pale yellow & yellow & $450(420,480)$ \\
\hline Cr. laurentii var. magnus & $\begin{array}{l}\text { dull yellow } \\
\text { orange }\end{array}$ & yellow & $450(420,480)$ \\
\hline T. luteola & yellow orange & yellow & $450(420,480)$ \\
\hline Cr. neoformans CBS str. & yellow orange & colorless & - \\
\hline Cr. neoformans Conant str. & dull yellow & colorless & - \\
\hline T. histolytica Tanner str. & yellow orange & colorless & - \\
\hline T. histolytica original str. & yellow orange & colorless & - \\
\hline Saccharomyces lithogenes & dull yellow & colorless & - \\
\hline
\end{tabular}

other Cryptococci (27). These lead to the conclusion that the intracellular pigment of $\mathrm{Cr}$. neoformans could not be recognized as a carotenoid.

It is not so difficult to seek other different points between $\mathrm{Cr}$. neoformans and the other Cryptococci.

Benham (1955) (20) pointed out that the two groups of Cryptococcus were distinguishable each other in the ability to grow at $37^{\circ} \mathrm{C}$ and in the parasitic activity to the brain of mice. She stated in her review on Cryptococcus (1956) (21) that the medical mycologists had found the properties necessary not only to identify these organisms, but also to distinguish between the pathogenicity and non-pathogenicity.

Wickerham (1952) (22) suggested that Cryptococcus could be related to an ascogenous yeast, Lipomyces, and Benham (1955a) (23) observing plurispored asci in one strain of $\mathrm{Cr}$. neoformans isolated from a dog brain, concluded that $\mathrm{Cr}$. neoformans and Lipomyces starkeyi might be one and the same organism. In our results, the production of carotenoid pigments could not be demonstrated in two Lipomyces species. Before Benham, the ascospore formation in $\mathrm{Cr}$. neoformans had been reported by Todd and HerrmanN (1936) (24), Redaelli et al. (1937) (25) and Giordano (1938) (26), while on the other Cryptococci the property have never been known.

These results indicate that $\mathrm{Cr}$. neoformans should be separated from the other species designated as Cryptococcus by LoDDer and KREGER-VAN RIJ 


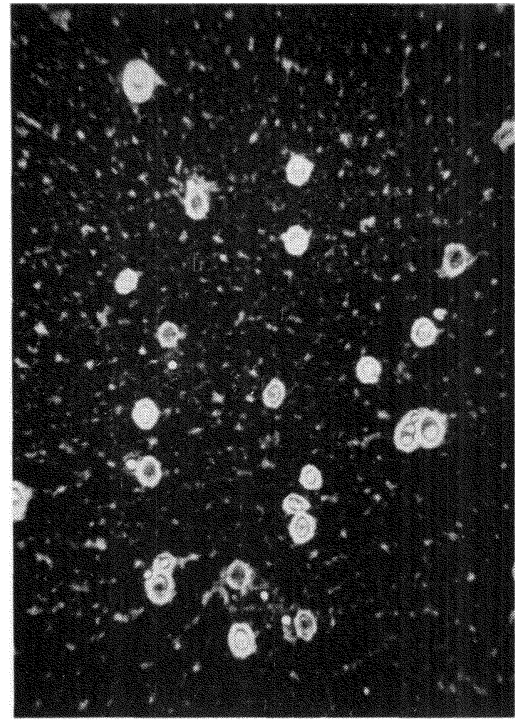

I

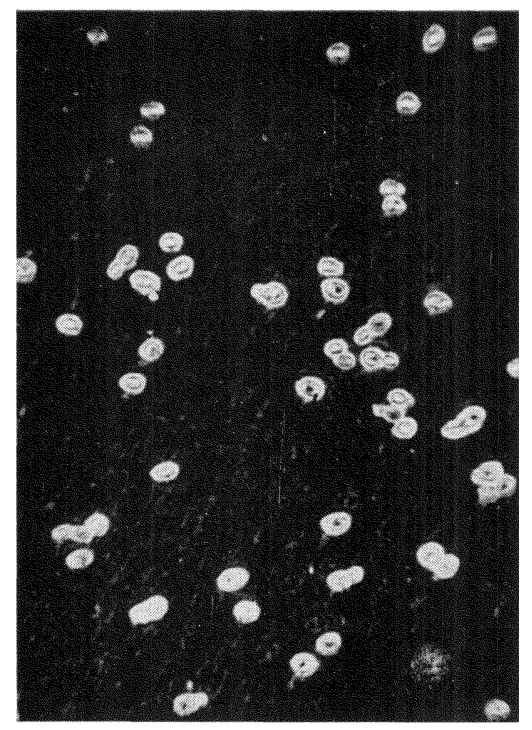

III

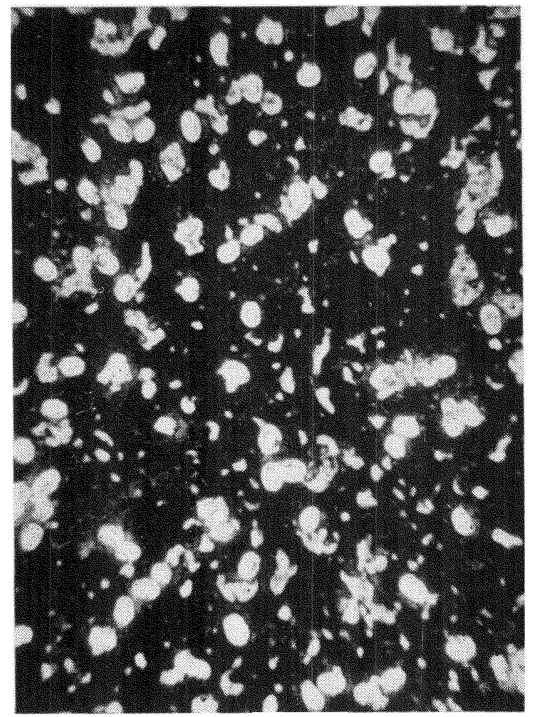

II

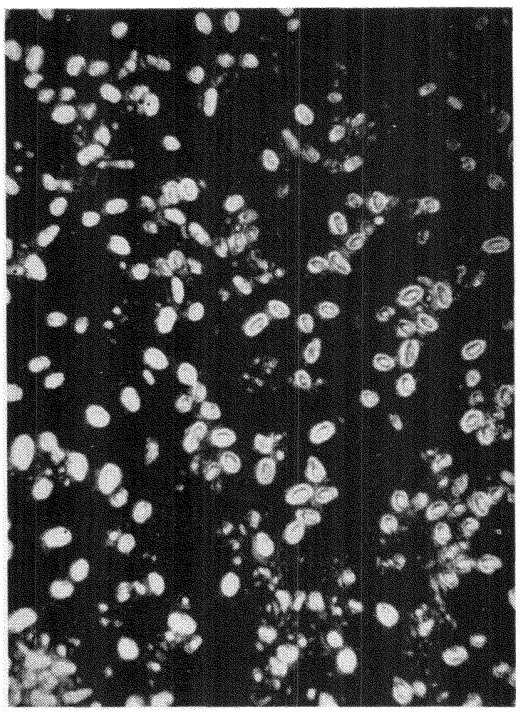

IV

The emergence of capsule of Rhodotorula cells with indian ink.

I . Rhodotorula glutinis strain koishikawensis, IFO. 0880.

II. Rhodotorula glutinis var. dairenensis, IFO. 0415.

III. Rhodotorula rubra strain corallina, IFO. 0406.

IV. Rhodotorula peneaus, IFO. 0930. 
(1952) and the opinion further induces us to move the latters into Rhodotorula leaving the former in Cryptococcus.

On the above conclusion, the vitamin requirement of these newcomers in Rhodotorula was investigated for the purpose of elucidation of their taxonomic relationships to the original Rhodotorulas. All of them required only thiamine essentially except one strain, Torula flavescens, requiring no vitamin, and their thiamine requirement could be divided into two types each of which coincides with those in Flavotorula respectively. (Table 4) (HASEgawa et al. 1960) (27) Therefore, they could be regarded as members of Flavotorula from the viewpoints of the vitamin requirement as well as of carotenogenesis.

Table 4. Types of the thiamine requirement by Cryptococci.

\begin{tabular}{l|c|c|r|r|r|r}
\multicolumn{1}{c|}{ Strains } & $\begin{array}{c}\text { Cultures } \\
\text { examined }\end{array}$ & Thiamine & $\mathrm{P}+\mathrm{T}$ & $\mathrm{P}$ & $\mathrm{T}$ & None \\
\hline Torula gelatinosa & 3 & 100 & 95 & 4 & 4 & 4 \\
Torula albida & 2 & 100 & 100 & 5 & 5 & 4 \\
Cryptococcus diffuens & 1 & 100 & 85 & 4.5 & 4.5 & 3 \\
Cryptococcus laurentii & 1 & 100 & 100 & 2.8 & 5 & 1.5 \\
Torula flava & 2 & 100 & 100 & 12 & 5 & 5.5 \\
Cryptococcus albidus & 1 & 100 & 80 & 58 & 75 & 4.5 \\
Torulopsis liquefaciens & 1 & 100 & 100 & 76 & 61 & 0 \\
Torula aurea & 2 & 100 & 100 & 95 & 90 & 25 \\
Cryptococcus laurentii var. & 1 & 100 & 97 & 53 & 46 & 3.1 \\
magnus & 2 & 100 & 83 & 72 & 37 & 5 \\
Torula luteola & 1 & 100 & 70 & 50 & 62 & 3 \\
Rhodotorula peneaus & 1 & 100 & 77 & 55 & 21 & 2.7 \\
Rhodotorula crocea & 6 & 100 & & & & 100 \\
Torula flavescens & & & & &
\end{tabular}

$\mathrm{P}$ : Pyrimidine moiety $\mathrm{T}$ : Tiazole moiety

Each value of the growth is shown in percentage of the optical density of a week culture to that in the medium to which vitamins are completely added.

\section{The general aspects of the subgenus Flavotorula}

The subgenus is distinguished from Rubrotorula by the colony color due to the carotenoid pigments which is yellow, dull yellow, pale yellow orange, pale orange and so on, and by the positive iodine reaction of the extracellular polysaccharide with the exception of Rht. flava and Rht. crocea.

The strains belonging to the subgenus are as follows.

Group 1. Rhodotorula flava (SAIto) Lodder (11), (31)

Rhodotorula crocea (Shifrine) and PhafF (28)

Group 2. Rhodotorula peneaus Phaff, Mrak and Williams (29) Torula laurentii Kufferath (30) 
Torula aurea SAITO $(31)$

Torula flavescens SAITo (31)

Cryptococcus laurentii var. magnus Lodder et KREGER-van RiJ (11)

Group 3. Torula albida SaIto (31)

Torula gelatinosa SAIto (31)

Torulopsis liquefaciens SAITo et OdA (32)

Group 4. Torula luteola Sarto (31)

Torulopsis diffluens $\mathrm{Z}_{\mathrm{ACH}}(33)$

Among these, Rhodotorula crocea was regarded as a lactose non-utiliser by the original authors, but in our result, an authentic culture, Y.C.C. 5214 sent from California showed a weak positive growth on the medium containing lactose as the sole source of carbon. Besides, there is a great morphological resemblance between the strain and Rht. flava. Therefore, the former should be regarded to be synonymous with the latter.

The strains of Group 2 show various color shades in their colonies on solid media, i.e. dull yellow, dull yellow orange, pale yellow orange or pale orange. Nevertheless, there is a great difficulty in the way of distinguishing them by their physiological properties. It seems to be an unavoidable consequence to regard them as the same species.

The strains of Group 3 coincided well with each other in the weak assimilability of galactose and lactose. Lodder and KREGer-van RIJ (11) brought them into Cryptococcus albidus whose name was originated from SAIto's Torula albida. This name, however, is not suitable for them from the point of their carotenogenic nature. They should be renamed Rhodotorula gelatinosa. The name owes its origin to $T$. gelatinosa which finds mention in the same literature as T. albida does.

Group 4 is characterized by the inactivity for lactose. Two strains of the group are clearly distinguished from each other in the assimilation of nitrate. Torulopsis diffuens much resembled to the strains of Group 3 except the assimilability of lactose which seems to be variable even in Group 3. As the result, this strain is considered to be closely related to Group 3, but we cannot yet have any proof of their identity.

Generally speaking, the system cannot exclude the possibility that some faded color mutant of Rubrotorula might be recognized as Flavotorula. When we obtained a color mutant of Rhodotorula glutinis, it was observed that the mutant was practically indistinguishable from Flavotorula by the colony appearance. The fact seems to suggest a phylogenetic relationship between Rubrotorula and Flavotorula.

\section{A NEW METHOD OF CLASSIFICATION}

\section{Characteristics used for the taxonomic key}

In recent years, physiological properties have been used in many cases as the method of classification for microorganisms, but, from the historical 
viewpoint of taxonomy, morphological properties have been likely to be regarded as more important. LODDER (1934) (34), LoDDER and KREGER-VAN RIJ (1952) (11) classified first asporogenous yeasts based on the ability or inability of carotenoid formation because they believed that the deep coloration of the cells by the pigments gave a remarkable characteristic not only physiologically but also morphologically. But, as the result of studies by Nakayama et al. (1954) (12) and Peterson et al. (1954) (13), the pigments were also found in pale colored yeasts belonging to the LoDDER and KREGERvaN RIJ's Cryptococcus. Cell morphology has been used, hitherto, for the taxonomic key to the asporogenous yeast. The property, however, was concluded not to serve well for the classification of Rhodotorula. Nothing but physiological characteristics which have been found to be more stable genetically is available for the purpose.

1) Properties of carotenogenesis

Genus Rhodotorula may be separatable into 2 subgenera, i.e. Rubrotorula and Flavotorula by the property of major carotenoids produced. Rubrotorula shows yellowish red to orange appearance and has been commonly called the red yeast. The coloration of the colony is due to carotenoid pigments, such as torulene, torularhodin, $\beta$-carotene, $\gamma$-carotene and neurosporene.

Flavotorula shows such a color appearance as yellow, pale yellow orange and pale orange. These light colors of the colony are due to the weak formation of the pigments, and are heightened depending on the component of medium, temperature, light and so on. Therefore, in the subgenus, it is hardly possible to distinguish strains by the difference in this color range.

On determining light absorption spectrum of the pigments extracted from cells cultivated in potato-yeast extract broth, these two subgenera could be separated each other by the fact that the absorption maximum of Rubrotorula was at $480 \mathrm{~m} /$ and that of Flavotorula was at $450 \mathrm{~m} \mu$. An exceptional strain, Rhodotorula glutinis var. aurantiaca showed its absorption maximum at $470 \mathrm{~m} \mu$. Perhaps, it seems that a certain pigment formed by the strain may be differed from any pigment in the other Rhodotorulas. The fact was also pointed out by Peterson et al. (1958) (35).

Experimental method:

The yeast is incubated for 4 days or more at $28^{\circ} \mathrm{C}$ with $50 \mathrm{ml}$ of the potato yeast extract broth in $200 \mathrm{ml}$ Erlenmeyer flask on rotary shaker. One hundred $\mathrm{ml}$ of the culture broth is centrifuged. The isolated cells are washed with distilled water and then are extracted, being ground in a mortar, 3 times with acetone and 2 times with petroleum ether. These acetone and petroleum ether fractions are combined together into a separating funnel, and then distilled water is added to them until the pigments completely gather into the petroleum ether layer which results from a clear separation of two phases. Further extraction from the acetone-water layer is carried out twice with petroleum ether.

Three petroleum fractions are combined and washed 3 times with dis- 
tilled water. After being dried with a small amount of anhydrous sodium sulfate, the pigmented fraction is filtered through a filter paper, and then concentrated in nitrogen gas current.

Absorption spectrum of the extract is obtained for the wave length region from 350 to $520 \mathrm{~m} \mu$, using a spectrophotometer. If need be, the extract is saponified in $20 \% \mathrm{KOH}$ methanolic solution.

\section{Medium:}

Peeled sliced potato $200 \mathrm{~g}$.

Press yeast $30 \mathrm{~g}$.

Glucose $\quad 30 \mathrm{~g}$.

Distilled water $1 l$.

The medium is boiled for 30 minutes and centrifuged after cooling. The supernatant fluid is used. $\mathrm{pH}$ (5.5) is not adjusted.

2) The assimilability of carbonydrates

The assimilation test of three sugars, i.e., lactose, maltose and sucrose is available for the differentiation of the species and varieties in the genus. Especially, lactose plays a more important part in deciding a phylogenetic group of the subgenus Rubrotorula. However, the property is more or less unstable and when maintained on the medium without lactose, the cultures oftenly tend to loss the property.

On the other hand, there were reported two different results from the lactose assimilation test on the strains of Rhodotorula minuta by SKINNER and HuXley (36). One group in the strains showed negative, the other group weakly possitive, and an authentic culture from CBS coincided with the latter contrary to the negative data by the other authors $(11,31,34)$. These facts offer a caution in using the property for the classification and identification of a Rhodotorula strain.

Experimental method:

The synthetic basal medium mentioned below and five sugars, i.e. glucose, maltose, sucrose, galactose and lactose are used for the carbon assimilation test. Six $\mathrm{ml}$ of the solution without carbohydrate was pipetted into $16 \mathrm{~mm}$ test tube and autoclaved. One and a half per cent solution of each carbohydrate in distilled water is sterilized by passage through a Seitz filter, and $1.5 \mathrm{ml}$ of it is added to the above basal solution. The yeast cells grown on the potato yeast extract agar slant at $28^{\circ} \mathrm{C}$ for 3 days are took up to distilled water and washed by centrifugation. One drop of the appropriate suspension of them is inoculated in the medium to become $10^{3}$ cells per $\mathrm{ml}$ in inoculum size.

The tube is incubated at $28^{\circ} \mathrm{C}$ for 3 weeks. The yeast growth in the media containing each carbohydrate is estimated by the optical density of culture broth at intervals of one week.

Comparison of each growth with that in the glucose medium is used for the estimation of the assimilability of each sugar. 


\section{Medium:}

$\left(\mathrm{NH}_{4}\right)_{2} \mathrm{SO}_{4}: 5 \mathrm{~g}$, Carbohydrate: $39 \mathrm{~g}, \quad \mathrm{KH}_{2} \mathrm{PO}_{4}: 1 \mathrm{~g}, \quad \mathrm{MgSO}_{4} \cdot 7 \mathrm{H}_{2} \mathrm{O}$ : $0.5 \mathrm{~g}, \mathrm{CaCl}_{2} \cdot 2 \mathrm{H}_{2} \mathrm{O}: 0.1 \mathrm{~g}, \mathrm{NaCl}: 0.1 \mathrm{~g}$, Vitamins solution: $10 \mathrm{ml}$, distilled water: 11.

Vitamins solution:

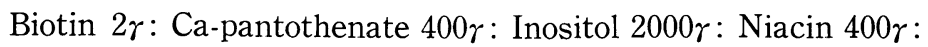
p-Aminobenzoic acid 200r: Pyridoxin- $\mathrm{HCl} 400 \gamma$ : Riboflavin 200r: Thiamine $\cdot \mathrm{HCl} 400 \gamma$ per $10 \mathrm{ml}$ distilled water.

3) The assimilability of nitrate

Nitrate utility has been generally accepted to be the most useful in the classification of yeast. Rhodotorula is fairly separated into two groups on the property, except an intermediate type which assimilates nitrate weakly. The strain having the exceptional characteristic which was genetically stable, was named Rhodotorula glutinis var. dairenensis.

\section{Experimental method:}

The same method as that for the carbon assimilation test is employed for the test. The liquid medium is also the same except that as the carbon source, 3 per cent glucose is employed and as the nitrogen source, 0.078 per cent $\mathrm{KNO}_{3}$ or 0.1 per cent $\left(\mathrm{NH}_{4}\right)_{2} \mathrm{SO}_{4}$.

The extent of growth in the nitrate medium is compared with that in the medium with $\left(\mathrm{NH}_{4}\right)_{2} \mathrm{SO}_{4}$.

4) The vitamin requirement test

The parallelity between the vitamin requirement and the other physiological properties seems to be a remarkable feature of the genus. There were found three phylogenetic groups characterized by the vitamin requirement, and the results of the test of requirement also fairly corresponded to the serological data by Tsuchiya et al. (1957) (38). One of the groups is characterized by the requirement of p-aminobenzoic acid and by the lactose assimilability in Rubrotorula. The requirement of p-aminobenzoic acid is very uncommon in yeasts, and is more stable characteristic than the lactose assimilability. Therefore, the property seems to be suitable for the taxonomic key to the species.

Two different patterns in the requirement of thiamine were found among the subgenera respectively. One is for the pyrimidine moiety. It exists in the strains belonging to Rubrotorula. The other type is for the both moieties, i.e., pyrimidine and thiazole. This type is a characteristic of Flavotorula. These properties are able to serve well for the differentiation of the subgenera, as well as the colony colors

\section{Experimental method:}

The synthetic basal medium mentioned above is also employed for the test. Ten kinds of media are prepared; one medium containing eight vitamins completely, eight kinds of media containing seven vitamins and free from each one respectively, and one medium containing no vitamin.

The procedure of inoculation, incubation and of the estimation of growth 
is the same as that was explained in the carbon assimilation test. The extent of vitamin requirement is decided turbidimetrically by the comparison of growth between in each vitamin deficient medium and in the complete medium.

5) The production of a starch-like compound

LODDER and KREGER-VAN RIJ (1952) (11) used the property as one of the characteristics defining the genus Cryptococcus, but it was also found in other genera; i.e. Rhodotorula, Trichosporon, Candida and so on. In the genus Rhodotorula, this character is usually found in Flavotorula strains.

Wickerham (1952) (22) pointed out that this might serve better as a guide to the type of yeasts occurring in a phylogenetic line than as a principal characteristic by which genera could be defined.

Experimental method:

The yeast is inoculated in $50 \mathrm{ml}$ of the synthetic basal medium and incubated on rotary shaker at $28^{\circ} \mathrm{C}$ for 3 weeks. Then a small portion of culture broth is took up from the flask to a test tube and mixed with a drop of Lugol's solution. When the organism have formed the starch like compound, the broth turns to blue or purple-green or violet color. (WicherhaM (22))

\section{The taxonomic descriptions}

1) Taxonomic position of the genus

LodDer (1934) (34), Buchwald (1939) (39) brought the genus into the family Rhodotorulaceae belonging to the Fungi Imperfecti or Deuteromycetes. But in 1952, LodDer and Kreger-van RIJ (11) gathered the asporogenous yeasts in only one family, Cryptococcaceae and divided the family into three subfamilies, i.e., Cryptococcoideae, Trichosporoideae and Rhodotoruloideae. The taxonomic position of the genus is as follows.

Deuteromycetes-Cryptococcales-Cryptococcaceae-Rhodotoruloideae-

Rhodotorula

2) Descriptions of the genus and subgenera

Genus Rhodotorula HARRISON (44)

Cells round, oval to elongate, reproduction by multilateral budding. Occasionally a primitive pseudomycelium. The cells are often surrounded with distinct capsule. On liquid medium, a ring is usually formed. Strictly oxidative dissimilation and no fermentation. The cultures on solid media have often a mucous appearance. Red to yellow pigments of carotenoid nature are produced. The genus consists of two subgenera named Rubrotorula and Flavotorula.

Subgenus Rubrotorula nov. Subgen.

Cells round, oval or elongate. Round and oval cells, $2-5 \times 2.5-8.5 \mu$, the shape comparatively stable, but they often change to elongate forms during successive cultivation. Elongate cells, $2-5 \times 10-28 \mu$, the length usually vari- 


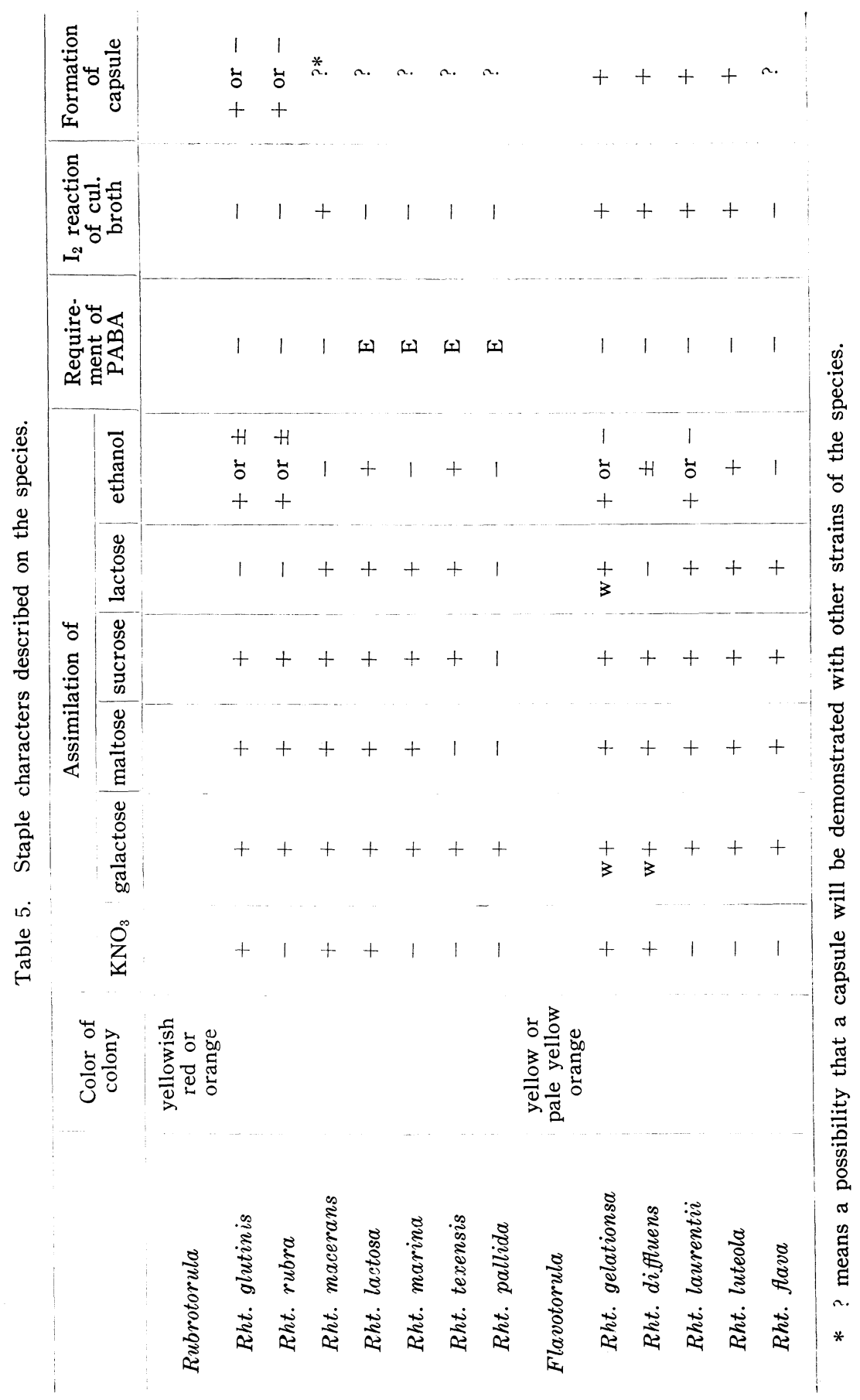


able with cultural conditions. Colony color due to carotenoid pigments, red to orange. The absorption maximum of the crude pigments extracted from the cells in the potato-yeast-ex. medium is at $480 \mathrm{~m} \mu$. Iodine reaction for the starch in the culture broth usually negative. Thiamine requirement in the subgenus is filled with the pyrimidine moiety.

Subgenus Flavotorula nov. Subgen.

Cells round, oval or long oval. The cells, 2.5-6.0 $\times 4.0-8.0 \mu$, occasionally, large spherical, up to $13 \mu$ dia., usually surrounded with a distinct capsule. Colony color due to carotenoid, reddish yellow to pale yellow, sometimes pale orange shade. The absorption maximum of the crude pigments extracted from the cells in the potato-yeast-ex. medium is at $450 \mathrm{~m} \mu$. Iodine reaction with starch in the broth, usually positive. The strains in the subgenus have commonly a thiamine requirement due to defficiency of the both pyrimidine and thiazole moieties.

3) Key to the species

\section{Subgenus Rubrotorula}

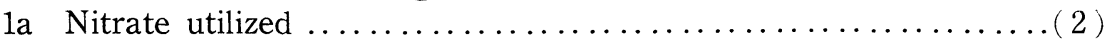

1b Nitrate not utilized ................................ 4 )

2a PABA essentially required, lactose assimilated........ Rht. lactosa

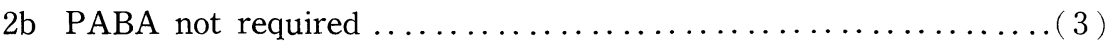

3a Lactose assimilated, starch reaction positive......... Rht. macerans

3b Lactose not assimilated........................ glutinis

Nitrate weakly assimilated..........Rht. glutinis var. dairenensis

Colony peculiarly colored, yellowish orange ............

Rht. glutinis var. aurantiaca

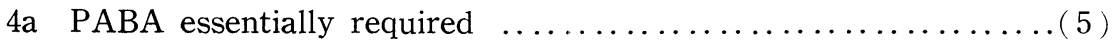

4b PABA not required, lactose not assimilated........... Rht. rubra

5a Maltose, lactose and sucrose assimilated ........... Rht. marina

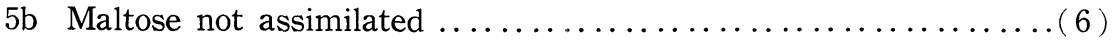

6a Lactose and sucrose assimilated ................... texensis

$6 \mathrm{~b}$ Lactose not or very weakly assimilated, sucrose assimilated Rht. texensis var. minuta

6c Lactose and sucrose not assimilated.............. Rht. pallida Subgenus Flavotorula

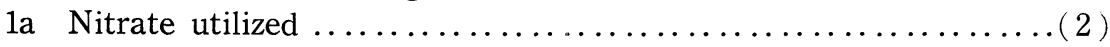

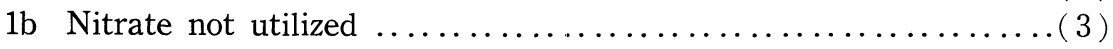

2a Lactose assimilated $\ldots \ldots \ldots \ldots \ldots \ldots \ldots \ldots \ldots \ldots$. . . gelatinosa

2b Lactose not assimilated ....................... diffluens

3a Lactose assimilated ............................... (4)

3b Lactose not assimilated ...................... luteolus

4a Starch reaction positive ..................... laurentii

$4 \mathrm{~b}$ Starch reaction negative $\ldots \ldots \ldots \ldots \ldots \ldots \ldots \ldots \ldots$. Rht. flava

4) Descriptions of the species

I. RHODOTORULA GLUTINIS (Fres.) Harrison emend. Hasegawa (37) 
Synonyms:

Cryptococcus glutinis Fresenius (1852) (40)

Saccharomyces glutinis (FRES.) СоHN (1875) (41)

Torula glutinis (Fres.) Pringsheim et Bilewsky (1911) (42)

Torula rubescens SAITo (1922) (31)

Torula rufula SAIto (1922)

Mycotorula rubescens (SAITo) Cif. et Red. (1925) (43)

Torulopsis rufula (SAIto) Cif. et Red. (1925)

Torulopsis bronchialis CIF. et RED. (1925)

Torulopsis saitoi $\mathrm{CIF}_{\mathrm{IF}}$. et RED. (1925)

Rhodotorula rufula (SAITo) HARRISON (1928) (44)

Rhodotorula rubescens (SAITO) HARRISON (1928)

Torula miniata Okunuki (1931) (45)

Torula koishikawensis OKUNUKI (1931)

Torula suganii ОкиNUкі (1931)

Rhodotorula bronchialis (CIF. et RED.) LoDder (1934) (34)

Rhodotorula suganii (OKUNUKI) LODdeR (1934)

Rhodotorula glutinis (Fres.) Harrison var. rufula (SAIto) Lodder (1934)

Rhodotorula glutinis (Fres.) Harrison var. saitoi (CIF. et Red.) LodDER (1934)

Rhodotorula longissima LODDER (1934)

Rhodotorula glutinis (Fres.) HARRISON var. rubescens (SAITo) Lodder (1934)

Rhodotorula glutinis (Fres.) HARRISON var. lusitanica MARC., Fed., et G. (1945) (35)

Standard description of the species:

Cells on malt extract agar, after 3 days at $25^{\circ} \mathrm{C}$, oval or round $2-5$ $\times 4-9 \mu$, single or in pairs or rarely in short chains. In some strains, cells are surrounded by a capsule. After one month at room temperature, the streak culture smooth and shiny, somewhat mucous. The color of colony reddish orange to orange. No fermentation. Assimilates glucose, galactose, maltose and sucrose, but not lactose. Utilization of nitrate. In ethyl alcohol medium, fair or weak growth. No requirement of vitamins. Iodine reaction of the extracellular polysaccharide, negative. Arbutin splitting, positive.

II. RHODOTORULA GLUTINIS (Fres.) Harrison var. AURANTIACA Hasegawa (37)

Synonyms:

Torula aurantiaca SAITo (1922) (31)

Torulopsis aurantiaca (SAITo) CIF. et RED. (1925) (43)

Chromotorula aurantiaca (SAITo) HARRISON (1928) (44)

Rhodotorula aurantiaca (SAITo) LODDER (1934) (34)

Standard description of the variety: 
Cells on malt extract agar, after 3 days at $25^{\circ} \mathrm{C}$, long oval or elongate, $2-3 \times 5-6-15 \mu$, single or in pairs. In some cases, cells are surrounded by a capsule. After one month at room temperature, the streak culture smooth and shiny. The colour of colony, yellowish orange. The absorption maximum of the crude extract of pigments is at $470 \mathrm{~m} \mu$. No fermentation. Assimilates glucose, galactose, maltose and sucrose, but not lactose. Utilization of nitrate. In alcohol medium, no growth. Stimulative requirement of vitamins. Iodine reaction of the extracellular polysaccharide, negative.

III. RHODOTORULA GLUTINIS (FrES.) HARRISON var. DAIRENENSIS Hasegawa et Banno (46) Synonym:

Torula rubra Schimon var. $\alpha$ (SAITo, 1922) (31)

Standard description of the variety:

Cells on malt extract agar, after 3 days at $25^{\circ} \mathrm{C}$, round or short oval, single or in pairs, $2.5-3.5 \times 3.5-4.5 \mu$. Cells are usually surrounded by a capsule. After one month at room temperature, the streak culture smooth, glistening and mucous; the color of colony, reddish orange. No fermentation. Assimilates glucose, galactose, sucrose, maltose but not lactose. Weak utilization of nitrate. Arbutin splitting positive. In ethyl alcohol medium, very poor growth. Stimulative requirement of thiamine. Iodine reaction of the extracellular polysaccharide, negative.

IV. RHODOTORULA MACERANS Sonne Fredericksen (15)

Standard description of the species:

Cells on malt extract agar, after 3 days at $25^{\circ} \mathrm{C}$, oval or long oval, single or in pairs, $3-5 \times 7-12 \mu$. The capsule of cell can not be recognized. After one month at room temperature, the streak culture smooth, glistening but not mucous; the color of colony, light yellowish red. No fermentation. Assimilates glucose, sucrose, maltose and lactose. Weak assimilation of galactose. Nitrate utilized. Arbutin splitting, positive. In ethyl alcohol medium, no growth. Essential requirement of biotin. Iodine reaction of the extracellular polysaccharide, positive.

\section{RHODOTORULA LACTOSA Haseigawa (47)}

Standard description of the species:

Cells on malt extract agar, after 3 days at $25^{\circ} \mathrm{C}$, short oval 2.5-3.5 $\times 3-6 \mu$, single. The capsule of cell can not be recognized. After one month at room temperature, the streak culture smooth, shiny and mucous; the color of colony, carrot pink. No fermentation. Assimilates glucose, sucrose, galactose, lactose and maltose (weak). Nitrate utilized. Growth in ethyl alcohol medium, positive. Essential requirement of para-aminobenzoic acid. Iodine reaction of the extracellular polysaccharide, negative. Arbutin splitting, positive. 
VI. RHODOTORULA RUBRA (Demme) Lodder emend. Hasegawa (38) Synonyms:

Saccharomyces ruber Demme (1889) (48)

Cryptococcus ruber (Demme) Vuillemin (1901) (3)

Torula mucilaginosa JoRgensen (1909) (49)

Torula sanguinea Schimon (1911) (50)

Cryptococcus ludwigi ANDERSon (1918) (51)

? Torula sanguinea Schimon (SAIto, 1922) (31)

Cryptococcus mena Fontoynont et Boucher (1923) (52)

Torulopsis sanguinea (Schimon) CIFERRI et RedaelLi (1925) (43)

Blastodendrion carbonei CIF. et RED. (1925)

Eutorulopsis dubia CIF. et RED. (1925)

Mycotorula pulmonalis CIF. et RED. (1925)

Torulopsis sanniei CIF. et RED. (1925)

Torulopsis biourgei CIF. et RED. (1925)

Blastodendrion simplex CIF. et RED. (1925)

Cryptococcus rubrorugosus CASTELLANI (1927) (54)

Cryptococcus pararoseus CASTELLANI (1927)

Rhodotorula sanguinea (SchimoN) HARRISON (1928) (44)

Rhodotorula aclotiana HARRISON (1928)

Torulopsis nitritophila CifERRI et ASHFord (1930) (55)

Cryptococcus radiatus A. et R. SARTORY et MeYer (1931) (56)

Torula decolans OKUNUKI (1931)

Torulopsis mannitica CASTELLI (1932) (57)

Torulopsis rubra (Demme) De Almeida (1933) (58)

Rhodotorula mucilaginosa (JöRG.) HARRISON (1928)

Rhodotorula mucilaginosa (JöRG.) H. var. sanguinea ( $\mathrm{ScH}$. ) Lodder (1934)

Rhodotorula mucilaginosa (JöRG.) H. var. carbonei LoDDER (1934)

Cryptococcus sanniei (CIF. et Red.) NANnizzi (1934) (59)

Rhodotorula sanniei (CIF. et Red.) Lodder (1934) (34)

Rhodotorula mucilaginosa (JöRg.) H. var. pararosea (CAST.) LoddeR (1934)

Torulopsis aurantia $\mathrm{Z}_{\mathrm{ACH}}(1934)(33)$

Torula aclotiana nom. nud.

Rhodotorula mucilaginosa (JöRG.) H. var. plicata LodDer (1934)

Rhodotorula rubra (D.) L. var. longa LoDDER (1934)

Rhodotorula rubra (D.) L. var. curvata LoDder (1934)

Torulopsis mena (F. et B.) Dodge (1935) (53)

Rhodotorula pilimanae HEDRICK et BURKe (1951) (60)

Standard description of the species:

Cells on malt extract agar, after 3 days at $25^{\circ} \mathrm{C}$, usually round and short oval or oval, $3-3.5 \times 4-5 \mu$ or $3-3.5 \times 5-7.5 \mu$; the shape of cell usually stable, but occasionally, it changes to elongate form during suc- 
cessive cultivation. In some strains, cells are surrounded by a capsule.

After one month, the streak culture, smooth and shiny, often mucous. The color of colony, pink, yellowish red, reddish orange to orange. No fermentation. Assimilates glucose, galactose, maltose and sucrose, but not lactose. Nitrate not utilized. In ethyl alcohol medium, fair or weak growth. Iodine reaction of the extracellular polysaccharide, negative. Arbutin splitting, positive.

Almost all the above synonymous strains of the species requires thiamine stimulatively, but only one strain requires other vitamins.

This strain was isolated by SAIto in 1922 and named? Torula sanguinea Schimon. The lineal descendants of the strain were examined, which had been maintained in four organs in Japan. The various results were obtained. Two cultures of them required essentially nicotinic acid and another one required stimulatively inositol in stead of thiamine. And the remaining one required stimulatively total of the vitamins tested. These seemed to result from dissociation of an extraordinary strain which was originally a labile form. SAITo described that the organism had elongate cells.

VII. RHODOTORULA MARINA Phaff, Mrak et Williams (29)

Synonym:

Rhodotorula tokyoensis KoBayashi (1953) (61)

Standard description of the species:

Cells on malt extract agar, after 3 days at $25^{\circ} \mathrm{C}$, oval or long oval, single or in pairs or in short chain, $2.5-4.5 \times 4-7.5 \mu(2.6-5.1 \times 3.1-11.5 \mu$ by the original authors). The capsule of cells can not be recognized. After one month at room temperature, the streak culture smooth, glistening but not mucous; the color of colony, yellowish red. No fermentation. Assimilates gulcose, maltose, sucrose, galactose and lactose (weak). Nitrate not utilized. In ethyl alcohol medium, no growth. Essential requirement of paraaminobenzoic acid. Iodine reaction of the extracellular polysaccharide, negative. Arbutin splitting, positive.

KoваYASHI's strain assimilated maltose weakly and besides the essential requirement of paraaminobenzoic acid, it requires thiamine stimulatively. This strain was renamed Rhodotorula marina PHAFF MraK, et Williams strain tokyoensis (KoBayashi) nov. stat.

VIII. RHODOTORULA TEXENSIS PhafF, Mrak et Williams (29)

Standard description of the species:

Cells on malt extract agar, after 3 days at $25^{\circ} \mathrm{C}$, oval single or in pairs or in short chain, $3 \times 4-6 \mu(2.5-5 \times 3-6 \mu$ by the original authors). The capsule of cells can not be recognized. After one month at room temperature, the streak culture smooth, glistening, but not mucous; the color of colony, pale reddish orange. No fermentation. Assimilates glucose, galactose, sucrose and lactose but not maltose. Utilization of nitrate, negative. Growth in ethyl alcohol medium, positive. Essential 
requirement of paraaminobenzoic acid. Iodine reaction of the extracellular polysaccharide, negative. Arbutin splitting, positive.

IX. RHODOTORULA TEXENSIS PhafF, Mrak et Williams (29) var. MINUTA (SAITo) nov. comb.

Synonyms:

Torula minuta SAITo (1922) (31)

Torulopsis minuta (SaIto) Ciferri et Redaelli (1925) (43)

Rhodotorula minuta (SAITo) HARRISON (1928) (44)

Standard description of the variety:

Cells on malt extract ager, after 3 days at $25^{\circ} \mathrm{C}$, oval, single or in pairs, $3 \times 4-6 \mu$. The capsule of cells can not be recognized. After one month at room temperature, the streak culture smooth, glistening, but not mucous; the color of colony, light reddish orange. No fermentation. Assimilates glucose, galactose, sucrose and not maltose. No or very weak assimilation of lactose. No utilization of nitrate. Growth in ethyl alcohol medium, positive. Besides the essential requirement of paraaminobenzoic acid, thiamine is stimulatively required. Iodine reaction of the extracellular polyasccharide, negative. Arbutin splitting, positive.

X. RHODOTORULA PALLIDA LODdER (34)

Standard description of the species:

Cells on malt extract agar, after 3 days at $25^{\circ} \mathrm{C}$, oval, single or in pairs, 3-4 $\times 4-6.5 \mu$. The capsule of cells can not be recognized. After one month at room temperature, the streak culture smooth, shiny but not mucous; the color or colony, pink. No fermentation. Assimilates gulcose and galactose, but not maltose, sucrose and lactose. Nitrate not utilized. In ethyl alcohol medium, no growth. Arbutin splitting, positive. Iodine reaction of the extracellular polysaccharide, negative.

Besides the essential requirement of para-aminobenzoic acid, thiamine is stimulatively required. Arbutin splitting, positive.

XI. RHODOTORULA GELATINOSA (SAIto) nov. comb.

Synonyms:

Torula gelatinosa SAITo (1922) (31)

Torula albida SAITO (1922)

Torulopsis albidus (SAITO) LoddeR (1934)

Torulopsis liquefaciens SaIto et Oda (1934)

Cryptococcus albidus (SAIto) Skinner (1947) (62)

Standard description of the species:

Cells on malt extract agar, after 3 days at $25^{\circ} \mathrm{C}$, round or oval, $3.0-7.0 \times 4.0-8.0 \mu$, usually single or in pairs. The cells are surrounded by a distinct capsule. After one month, the streak culture, mucous and shiny, and the color of colony, pale yellow orange or pale orange. No fermentation. Assimilates glucose, sucrose, maltose, galactose (weak) and lactose (weak). Utilization of nitrate. In ethyl alcohol medium, 
growth or no growth. Essential requirement of thiamine. Iodine reaction of extracellular polysaccharide, positive. Arbutin splitting, positive.

XII. RHODOTORULA DIFFLUENS ( $\left.\mathrm{Z}_{\mathrm{ACH}}\right)$ nov. comb.

Synonyms:

Torulopsis diffluens $\mathrm{Z}_{\mathrm{ACH}}$ (1934) (33)

Torulopsis nadaensis SaITo et OdA (1934) (32)

Cryptococcus diffluens ( $\left.\mathrm{Z}_{\mathrm{ACH}}\right)$ LodDer et KREGER-vaN RIJ (1952) (11) Standard description of the species:

Cells on malt extract agar, after 3 days at $25^{\circ} \mathrm{C}$, round or oval, $3.5-6.0 \times 4.0-7.0 \mu$, single or in pairs. The cells are surrounded by a distinct capsule. After one month, the streak culture mucous and shiny, and the color of colony, pale yellow orange. No fermentation. Assimilates glucose, sucrose, maltose and galactose (weak), but not lactose. Utilization of nitrate. In ethyl alcohol medium, weak or no growth. Essential requirement of thiamine. Iodine reaction of extracellular polysaccharide, positive. Arbutin splitting, positive.

XIII. RHODOTORULA LUTEOLA (SaIto) nov. comb. Synonyms:

Torula luteola SaIto (1922) (31)

Chromotorula luteola (SAITo) HaRRISON (1928) (44)

Torulopsis luteola (SAITo) LodDER (1934) (34)

Cryptococcus luteolus (SAITo) LodDer et KREger-van RiJ (1952) (11) Standard description of the species:

Cells on malt extract agar, after 3 days at $25^{\circ} \mathrm{C}$, oval, long oval to elongate, $3.5-6.0 \times 5.5-12.0 \mu$, single or in pairs. The cells are surrounded by a distinct capsule. After one month, the streak culture, shiny and mucous, and the color of colony, dull yellow. No fermentation. Assimilates glucose, galactose, sucrose, maltose but not lactose. No utilization of nitrate. In ethyl alcohol medium, growth. Essential requirement of thiamine. Iodine reaction of extracellular polysaccharide, positive. Arbutin splitting, positive.

XIV. RHODOTORULA LAURENTII (KUFFERATH) nov. comb. Synonyms:

Torula laurentii Kufferath (1920) (30)

Torulopsis laurentii (Kuff.) Lodder (1934) (34)

Torula aurea SAITo (1922) (31)

Chromotorula aurea (SAITo) HARRISON (1928) (44)

Rhodotorula aurea (SAITo) LODDER (1934)

Rhodotorula peneaus PhafF, Mrak et Williams (1952) (29)

Cryptococcus laurentii var. magnus LodDer et Kreger-van RIJ (1952) (11)

Torula flavescens SAITo (1922) (31)

Torulopsis flavescens (SAITo) LodDER (1934)

Cryptococcus flavescens (Saito) Skinner (1947) (62) 
Cryptococcus laurentii var. flavescens (SAIto) Lodder et Kreger-van RIJ (1952)

Standard description of the species:

Cells on malt extract agar, after 3 days at $25^{\circ} \mathrm{C}$, round, oval, long oval and elongate, 2.0-4.5 $\times 2.5-6.0 \mu$. An extraordinary strain, Rht. laurentii strain magnus $(=C r$. laurentii var. magnus) has large sphaerical cells, $4.0-12 \times 4.5-13 \mu$. The cells are surrounded by a distinct capsule. After one month, the streak culture, shiny and mucous or smooth, and the color of colony, dull yellow, dull yellow orange, pale yellow orange, or pale orange. No fermentation. Assimilates glucose, galactose, sucrose, maltose and lactose. No utilization of nitrate. In ethyl alcohol medium, growth or no growth. Essential requirement of thiamine with one exception. The exceptional strain, Rht. laurentii strain flavescens $(=T$. flavescens) requires no vitamin, Iodine reaction of extracellular polysaccharide, positive. Arbutin splitting, positive.

XV. RHODOTORULA FLAVA (SAIto) Lodder (34)

Synonyms:

Torula flava SAITo (1922) (31)

Chromotorula flava (SAITo) HARRISON (1928) (44)

Rhodotorula crocea SHIFrine et PHAFF (1956) (28)

Standard description of the species:

Cells on malt extract agar, after 3 days at $25^{\circ} \mathrm{C}$, oval, and long oval, $3.0-5.0 \times 5.0-8.0 \mu$, single or in pairs. Cells has usually no capsule. After one month, the streak culture is yellow or yellow orange, dull, soft and slightly wrinkled. No fermentation. Assimilates glucose, galactose, sucrose, maltose and lactose. No utilization of $\mathrm{KNO}_{3}$. In ethyl alcohol medium, no growth. Essential requirement of thiamine. Iodine reaction of extracellular polysaccharide, negative. Arbutin splitting, positive.

\section{ACKNOWLEDGEMENT}

The authors wish to express their sincerest thanks to Dr. K. Sato, Dr. K. Sakaguchi and Dr. K. Arima for their guidance and encouragement extended throughout this work and heartily appreciate the valuable advices of Dr. R. Nakazawa, Dr. S. Kuwada and Dr. H. Naganishi. The author's grateful acknowledgements are also made to Dr. W. CH. Slooff, Dr. H. J. PhafF, Dr. L. J. Wickerham and Dr. B. L. Brady for their kindness in sending the authentic cultures of Rhodotorula and Cryptococcus. 


\section{REFERENCES}

(1) F. KütZING: Algarum aquae dulcis Germaniae, Decas III (1838).

(2) P. J. F. Turpin: Compt. Rend. Acad. Sc. 8, 369 (1838).

(3) A. Vuillemin: Rev. Gen. Sc. 12, 732 (1901).

(4) A. GUILLIERMOND: Les levures (1912).

(5) A. Guilliermond: Clef dichotomique pour la determination des levures (1928).

(6) R. Ciferri and P. Redaeldi: Ann. Mycol. 27, 243 (1929).

(7) A. BERLESE: Giorn. viticoltura enologia, 3, 52 (1895).

(8) C. W. DODGE: Medical mycology (1935).

(9) Rh. W. Benham: J. Infect. Dis. 57, 255 (1935).

(10) A. T. HENRICI: Bact. Rev., 5, 97 (1941).

(11) J. LODDER and N. J. W. KREGER-VAN RIJ: The yeast, a taxonomic study (1952).

(12) T. Nakayama, G. Machinney and H. J. PhafF: Antonie van Leeuwenhoek, J. Microbiol. 20, 217 (1954).

(13) W. J. Peterson, T. A. Bell, J. L. Etchells and W. W. G. Smart JR: J. Bact. 67, 708 (1954).

(14) H. J. Phaff, E. M. Mrak et O. B. Williams: Mycologia 44, 436 (1952).

(15) P. SonNe Frederiksen: Friesia, 5, 237 (1956).

(16) J. Lodder, W. Ch. Sloof and N. J. W. Kreger-van RiJ: "The chemistry and biology of yeasts" ed. A. H. CoOK (1958).

(17) J. Lodder and N. J. W. KReger-van RiJ: Lab. Practice 4, 56 (1955).

(18) J. MAGER and M. ASchNeR: J. Bact., 53, 283 (1947).

(19) T. Hasegawa, I. Asano and K. Mikata: Japanese J. Med. Mycol. 1, 156 (1960).

(20) Rh. W. Benham: Trans. N. Y. Acad. Sc., Ser. II., 17, 418 (1955).

(21) Rh. W. BenhaM: Bact. Rev. 20, 189 (1956).

(22) L. J. Wickerham: Ann. Rev. Microbiol. 6, 317 (1952).

(23) Rh. W. Benham: Proc. Soc. Exptl. Biol. Med. 89, 243 (1955a).

(24) R. L. Todd and W. H. Herrmann: J. Bact. 32, 89 (1936).

(25) P. Redaelli, R. Ciferri and A. Giordano: Boll. Sez. Ital. Soc. Intern. Microbiol. 1, 1 (1937).

(26) A. Giondano: Mycopathologia 1, 274 (1938).

(27) T. HASEGAWA and I. BANNO: J. Ferm. Tech. in press.

(28) M. ShifRine and H. J. PhAFF: Mycologia 48, 41 (1956).

(29) H. J. PhafF, E. M. MraK and O. B. Williams: Mycologia 44, 431 (1952).

(30) H. Kufferath: Ann. Bull. Soc. Roy. Sc. Med. Nat. Bruxelles 74, 16 (1920).

(31) K. SAITo: Japanese J. Botany 1, 1 (1922).

(32) K. SAITO and M. OdA: J. Ferm. Tech. 12, 159 (1934).

(33) S. Wolfram and F. ZACH: Arch. Dermatol. Syphil. 170, 681 (1934).

(34) J. LODDER: Die Anascosporogenenhefen (1934).

(35) W. J. Peterson, W. R. Evans, E. lecce, T. A. Bell and J. L. Etchells: $J$. Bact. 75, 586 (1958).

(36) C. E. SkINNER and M. J. HUXLEY: Mycologia 48, 371 (1956).

(37) T. HaSEGawa: J. Ferm. Tech. 36, 194 (1958).

(38) T. Tsuchiya, Y. Fukazawa, S.Amemiya, M. Yoneyama and K. Suzuki: Yokohama Medical Bulletin 8, 215 (1957).

(39) N. F. BUCHWALD: Fungi imperfecti (Deuteromycetes) (1939).

(40) G. Fresenius: Beitrage zur Mycologie (1950). 
(41) F. Cohn and J. Schroeter: Beitr. Biol. Pflanz. 1, 187 (1875).

(42) E.Pringsheim and H. Bilewski: Beitr. Biol. Pfanz. 10, 118 (1911).

(43) R. Ciferri and P. Redaelli: Att. Inst. Bot. R. Univ. Pavia, ser. I, 2, 147 (1925).

(44) C. F. HARrison: Trans. Roy. Soc. Canada V, 22, 187 (1928).

(45) K. OKunuKI: Japanese J. Bot. 5, 318 (1931).

(46) T. Hasegawa and I. Banno: J. Ferm. Tech. 36, 403 (1958).

(47) T. Hasegawa: J. Gen. Appl. Microbiology, 5, 30 (1959).

(48) R. Demme: Ann. de Microgr. (1889).

(49) A. JöRGENSEN: Die Mikroorganismen der Garungsindustrie (1909).

(50) O. Schimon: Beitrage zür Kenntnis Rot Gefärbter Niederen Pilze (1911).

(51) H. W. Anderson: J. Infect. Dis. 21, 341 (1917).

(52) M. Fontoynont and H. Boucher: Ann. Derm. Syphil. 6, 209, 318 (1923).

(53) C. W. DodGe: Medical mycology (1935).

(54) A. Castellani: Arch. Derm. Syphil. 16, 383 (1927).

(55) B. K. ASHFord and R. CifERri: Zentr. Bakt. Parasit. II, 81, 63 (1930).

(56) A. Sartory, R. Sartory and J. Meyer: Compt. Rend. Soc. Biol. 106, 597 (1931).

(57) T. Castelli: Giorn. Biol. App. Industr. Chim. Alim: 4, 1 (1932).

(58) F. P. De Almeida: Ann. Fac. Med. Sao Paulo 9, 69 (1933).

(59) A. NANNIZZI: Repertorio sistematico dei miceti dell uomo e degli animali (Trattato di micopathologia umana, G. PollaCI IV, 1934).

(60) L. R. HEDERICK and G. C. BURKe: Mycopathologia 6, 92 (1951).

(61) T. KoBAYASHI: Report of Wood Saccharification Discussion Committee 2, 93, (1953).

(62) C. E. Skinner, C. W. Emmons and H. M. TsuchiYA: Henrichi's Molds, yeasts and actinomycetes (1947).

(63) T. Hasegawa and I. Banno; J. Ferm. Technol. 37, 174 (1959). 